\title{
Karakteristik Nilai Kalor Briket Tebu Tibarau Sebagai Bahan Bakar Alternatif
}

\author{
Hendri Nurdin ${ }^{1 *}$, Hasanuddin ${ }^{1}$, Darmawi $^{1}$ \\ ${ }^{1}$ Jurusan Teknik Mesin, Fakultas Teknik, Universitas Negeri Padang \\ *Corresponding author, e-mail: hens2tm@yahoo.com
}

\begin{abstract}
Abstrak - Upaya dalam mendapatkan bahan bakar alternatif melalui pengembangan diversifikasi produk briket tebu tibarau. Salah satu bahan potensial sumber energi terbarukan yang dapat diolah menjadi bahan bakar briket yaitu tebu tibarau. Ketergantungan terhadap energi bahan bakar minyak (BBM) sebagai kebutuhan utama dapat dikurangi penggunaannya oleh masyarakat menengah ke bawah. Upaya dan inovasi briket tebu tibarau yang dihasilkan sebagai bahan bakar alternative sehingga mempunyai karakteristik terhadap kualitas dan performa yaitu nilai kalornya. Sebelum dikembangkan sumber potensi ini, diperlukan adanya tahapan ujicoba dan evaluasi sesuai tatanan alur pengembangan produk bahan bakar briket. Melalui teknologi proses pembuatan produk briket dengan kompaksi dan optimalisasi kandungan komposisi terhadap penggunaan perekat yang bermacam jenis sehingga diperoleh nilai kalornya. Dari penelitian ini dapat dihasilkan suatu pengembangan model produk briket tebu tibarau yang direkomendasikan sebagai bahan bakar alternatif. Karakteristik nilai kalor briket tebu tibarau yang maksimal dengan perekat inggu diperoleh sebesar $14608,36 \mathrm{~kJ} / \mathrm{Kg}$ pada komposisi $80 \%: 20 \%$ dan densitasnya sebesar $302,98 \mathrm{Kg} / \mathrm{m3}$. Penggunaan perekat dari jenis tanaman inggu dapat memperbesar karakteristik nilai kalor briket tebu tibarau sehingga dapat dinyatakan bahwa penggunaan perekat dapat mempengaruhi karakteristiknya. Perbandingan massa bahan baku (tebu tibarau) dengan perekat tapioka, besaran partikel, gaya penekanan (kompaksi), dapat mempengaruhi nilai kalor dan densitas briket tebu tibarau.
\end{abstract}

Kata kunci : briket, tebu tibarau, perekat, nilai kalor, energi

Abstract-Efforts in obtaining alternative fuels through the development of diversification of tibarau cane briquette products. One of the potential materials of renewable energy sources that can be processed into fuel briquettes is tibarau cane. Dependency on the energy of fuel as the main needs can be reduced its use by the middle to lower society. Efforts and innovations tibarau cane briquettes produced as alternative fuel so that it has characteristics to the quality and performance of caloric value. Before this potential source was developed, the necessary stages of testing and evaluation in accordance with the order of the development of fuel product briquettes. Through the process technology of briquette product making with compaction and optimization of the composition content on the use of adhesive of various types to obtain the calorific value. From this research can be produced a model development of tibarau cane briquette product recommended as alternative fuel. Characteristics of tibarau tibarau cane briquette maximum value with inggu adhesive obtained by 14608,36 $\mathrm{kJ} / \mathrm{Kg}$ at 80\%: $20 \%$ composition and density $302,98 \mathrm{Kg} / \mathrm{m3}$. The use of adhesives of inggu crop types can enlarge the characteristic heating value of tibarau cane briquettes so it can be stated that the use of adhesives may affect its characteristics. Comparison of mass of raw material (tibarau cane) with tapioca glue, particle size, pressure force (compaction), can influence the calorific value and density of tibarau cane briquette.

Keywords : briquettes, tibarau cane, adhesive, calorific value, energy

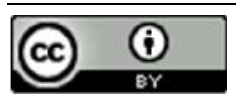

This is an open access article distributed under the Creative Commons 4.0 Attribution License, which permits unrestricted use, distribution, and reproduction in any medium, provided the original work is properly cited. $\odot 2018$ by Author and Universitas Negeri Padang

\section{Pendahuluan}

Kebutuhan energi di Indonesia dunia terus meningkat khususnya minyak bumi. Diperkirakan sumber utama energi Indonesia akan habis pada
2025 yang merupakan cadangan minyak bumi dalam negeri. Pada tahun 2015, konsumsi BBM dalam negeri sudah di atas 1,5 juta barel per hari, sementara produksinya di bawah 800.000 barel per 
hari. Kondisi ini mununjukkan adanya krisis energi dan/atau darurat energi (Krisdaren). Ketahanan energi nasional sebenarnya masih sangat rapuh dimana Indonesia tidak memiliki SPR (Strategic Petroleum Reserves), sehingga akan menjadikan negara ini pengimpor bahan bakar minyak terbesar di dunia [1]. Sehingga harus mengimpor sebesar 700.000 barel perhari. Pusat Studi Energi Asia Pasifik (APERC) memprediksi kebutuhan energi bahan bakar akan melonjak dari angka 1.087 juta ton setara minyak pada 2002 menjadi 1.991 juta ton setara minyak pada 2030. Jika tak ada upaya yang luar biasa untuk menekan konsumsi energi berbasis minyak atau mendorong penggunaan energi terbarukan, APERC memperkirakan Indonesia akan benar-benar mengandalkan impor untuk memenuhi kebutuhan energi dalam negeri pada 2030 [2]. Indonesia akan mengalami persoalan energi yang serius memasuki tahun 2020 akibat keterlambatan antisipasi dalam mengembangkan sumberdaya energi dan bahan bakar alternatif.

Kebutuhan energi yang semakin meningkat ini berdampak di tengah masyarakat dan membebani pemerintah, sehingga harus disubsidi bahan bakar yang berpengaruh terhadap kehidupan masyarakat. Dengan meningkatnya kebutuhan dan harga bahan bakar yang sulit diprediksi dalam satu dekade terakhir telah mendorong pengembangan bioenergi dan penggunaan energi terbarukan sebagai sumber energi alternatif. Pemerintah telah mengeluarkan Peraturan Presiden RI No. 5 Tahun 2006 tentang kebijakan energi nasional yang memuat ketentuan bahwa sumber energi alternatif tertentu adalah jenis sumber energi tertentu pengganti BBM [3]. Hal ini merupakan suatu peluang bagi segenap komponen bangsa untuk berpatisipasi aktif mengembangkan sumberdaya energi, termasuk tentunya potensi energi biomassa dari bahan limbah produksi industri dan hasil pertanian, seperti halnya pemanfaatan ampas tebu, kulit durian, arang batok/tempurung kelapa, dan sebagainya. Dalam Peraturan Presiden Republik Indonesia Nomor 79 Tahun 2014 Tentang Kebijakan Energi Nasional dirumuskan bahwa diperlukan peningkatan pemanfaatan sumber energi baru berbentuk padat dan sumber energi terbarukan dari jenis biomassa dan sampah [4]. Peraturan Presiden Nomor 41 Tahun 2016 tentang Tata Cara Penetapan Dan Penanggulangan Krisis Energi dan/atau Darurat Energi yang dilaksanakan oleh Dewan Energi Nasional (DEN) dalam rangka menjamin ketahanan energi nasional [5]. Percepatan akan penyediaan dalam berbagai pilihan dan adopsi energi alternatif merupakan salah satu langkah yang harus ditempuh ke depannya. Di antaranya hal ini dapat dicapai melalui produksi jenis bahan bakar padat, seperti briket berbahan baku tebu tibarau. Teknologi pembriketan bahan bakar dapat dilakukan dengan tiga metode yaitu pembriketan bertekanan tinggi, pembriketan tekanan medium dengan pemanas, pembriketan bertekanan rendah dengan bahan pengikat [6].

\section{StUdi Pustaka}

Pengembangan bioenergi sebagai sumber energi alternatif, di luar sumber energi fosil yang kian langka. Salah satu energi terbarukan yang mempunyai potensi besar di Indonesia adalah biomassa. Sebagaimana dalam kebijakan pengembangan energi terbarukan dan konversi energi Departemen ESDM (2016) disebutkan bahwa potensi energi biomassa di Indonesia cukup besar mencapai $49.8 \mathrm{GWe}$ [7].

Biomassa yang merupakan suatu limbah benda padat yang dapat dimanfaatkan kembali sebagai bahan bakar selain batu bara [8]. Limbah dan residu dari pertanian dan industri dapat digunakan sebagai sumber terbarukan alternatif untuk menghasilkan energi dan bahan baku seperti bahan kimia, selulosa, karbon dan silica [9]. Energi biomassa ini mencakup, bahan bakar dari kayu, limbah pertanian \& perkebunan/hutan, komponen bahan organik dari limbah industri dan rumah tangga. Beberapa energi alternatif yang bisa dikembangkan sebagai substitusi minyak bumi adalah geothermal, batu bara, dan biomassa (limbah). Untuk geothermal dan batu bara masih merupakan energi fosil kendatipun belum optimal pemakaian dan pengolahannya. Sehubungan dengan itu, diperlukan upaya mengoptimalisasikan pengembangan bahan-bahan dan sumber potential energy biomassa menjadi suatu bentuk produk inovatif bahan bakar yang dapat memenuhi tuntutan kebutuhan energi dan menjadikannya sebagai komoditas perdagangan.

Tanaman tebu tibarau merupakan alternatif sumber energi yang potensial karena tebu tibarau menghasilkan biomassa berupa ampas tebu (bagasse). Biomassa dapat dibakar dalam bentuk serbuk, briket, ataupun batangan. Briket merupakan metode yang efektif untuk mengkonversi bahan baku padat menjadi suatu bentuk hasil kompaksi yang lebih mudah untuk digunakan.

Pemanfaatan tebu tibarau yang belum tersentuh selama ini dapat dijadikan bahan bakar padat (briket) yang diproses dengan perpaduan bahan 
potensial sumber energi biomassa lainnya. Hal ini merupakan salah satu bentuk inovasi produk bahan bakar padat sehingga menjadi cikal bakal energi alternatif. Dengan melakukan diversifikasi sumber potensi energi yang berasal dari biomassa dapat meningkatkan iklim investasi dan kemampuan nasional dalam melaksanakan progam pemerintah.

Penelitian yang telah dilakukan pada tumbuhan tebu tibarau yang mendapatkan hasil berupa kemampuan tenaga panas bioethanol kadar rendah dan juga memiliki kandungan nilai energi panas/kalor terhadap air sarinya dengan proses fermentasi setelah mengalami distilasi [10]. Sebagai tumbuhan berserat alami yang mengandung lignoselulosa, tebu tibarau juga mengandung gula dengan kadungan kadar brix asal (niranya) berkisar antara 3\% - 6\% dan sedikit lebih rendah dari tanaman tebu budidaya yang mengandung kadar brix asal 8\% - 12\% [11]. Pelgia Research Library-Indian Institute of Technology melaporkan bahwa tumbuhan tebu tibarau memiliki kandungan kimia [12]. Potensi yang dimiliki tumbuhan tebu tibarau ini dapat direkomendasikan untuk bahan baku pengembangan bahan bakar nabati.

Sebelum produk briket tebu tibarau dikembangkan sebagai bahan bakar alternatif diperlukan adanya kajian evaluasi terhadap kualitas dan performanya berupa analisis karakteristik nilai kalor sehingga inovasi bahan bakar alternatif dapat diterapkan sebagai bentuk kontribusi dalam mencapai ketahanan energi nasional.

\section{Metode}

Dalam penelitian ini dilakukan kajian eksperimen terhadap karakteristik sampel uji briket tebu tibarau. Orientasi pelaksanaan difokuskan pada pembuatan dan pengembangan produk bahan bakar briket berbahan baku ampas tebu tibarau (Gambar 1, dan 2). Ampas tebu sebelumnya dicacah dan dijadikan partikel butiran (mesh) sebagai persyaratan.

Bahan perekat yang digunakan pada pembuatan briket ini yaitu tapioka, lempung, damar, inggu, kapur. Metode pembuatan briket ini dengan persentase optimal campuran sebagai varians, modifikasi penambahan bahan baku yang memiliki potensi sebagai campuran utama. Perbandingan campuran bahan baku berupa tebu tibarau dan perekat menggunakan persentase 80\% : 20\%. Varians campuran yang telah diaduk dan dipersiapkan, kemudian dilakukan pencetakan dengan tekanan kompaksi sebesar $100 \mathrm{kgf} / \mathrm{cm}^{2}$.
Model Briket tebu tibarau yang telah dicetak kemudian di dijemur pada panas matahari dalam beberapa hari.

Selanjutnya pengambilan sampel uji dari bagian briket yang sudah kering dan melakukan pengujian di laboratorium. Karakteristik yang diharapkan dengan penerapan metode yang tepat untuk menginventarisir, mengukur, menguji ataupun menganalisis parameter dan variabel penelitian yang ditetapkan akibat perlakuan dan kondisional.

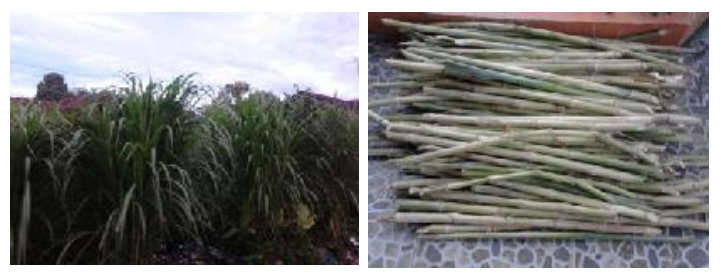

Gambar 1. Tanaman Tebu Tibarau

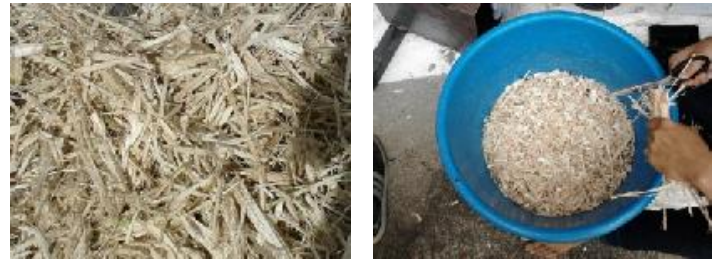

Gambar 2. Ampas Tebu Tibarau

Peralatan uji di laboratorium yang digunakan dalam penelitian ini berupa "Bomb Calorimeter" (Gambar 3) sesuai standar uji ASTM D-2015 dengan pengkondisian suhu ruangan yang stabil. Pengujian yang diperoleh berhubungan dengan energi panas pembakaran atau nilai kalor (calorific value).

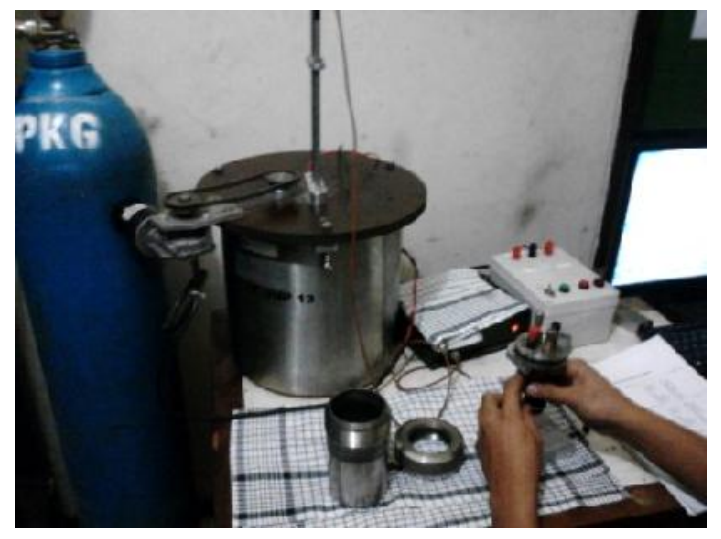

Gambar 3. Alat Bomb Calorimeter

Dalam analisis dari tiap jenis dan komposisi persentase bahan campuran serta parameter perlakuan akan di catat dan ditabulasikan pada tabel pendataan yang dirancang sesuai kebutuhan. 
Tabel 1. Karakteristik Briket Tebu Tibarau

\begin{tabular}{|c|c|c|c|c|}
\hline \multicolumn{2}{|c|}{ Komposisi Persentase } & \multirow{2}{*}{$\begin{array}{c}\text { Massa Kering } \\
\text { Briket } \\
\text { (m) } \\
\text { (gr) }\end{array}$} & \multirow{2}{*}{$\begin{array}{l}\text { Densitas } \\
\quad(\rho) \\
\left(\mathrm{Kg} / \mathrm{m}^{3}\right)\end{array}$} & \multirow{2}{*}{$\begin{array}{c}\text { Nilai Kalor } \\
\text { (CV) } \\
\mathbf{n}_{\mathbf{B B}} \\
(\mathrm{kJ} / \mathrm{Kg})\end{array}$} \\
\hline $\begin{array}{c}\text { Bahan Baku } \\
(80 \%)\end{array}$ & $\begin{array}{c}\text { Perekat } \\
(20 \%)\end{array}$ & & & \\
\hline Tebu Tibarau & Tapioka & 53,2 & 565,42 & 11221,72 \\
\hline Tebu Tibarau & Lempung & 41,0 & 379,85 & 9000,97 \\
\hline Tebu Tibarau & Damar & 36,0 & 333,53 & 13151,0 \\
\hline Tebu Tibarau & Inggu & 22,0 & 302,98 & 14608,36 \\
\hline Tebu Tibarau & Kapur & 22,6 & 311,24 & 10125,23 \\
\hline
\end{tabular}

Analisis data dan perhitungan menggunakan rumus baku yang ada dan diolah berbantuan komputasi. Nilai kalor tertinggi $\left(\mathrm{N}_{\mathrm{bb}}\right)$ dapat dihitung dengan persamaan:

$$
N_{b b}=\frac{\left(t_{2}-t_{1}\right) c_{v}}{m_{b b}} \quad(k J / K g)
$$

dimana:

$$
\begin{aligned}
& \mathrm{N}_{\mathrm{bb}}=\text { Nilai kalor briket } \\
& \mathrm{t}_{2}=\text { Temperatur Akhir }\left({ }^{\circ} \mathrm{C}\right) \\
& \mathrm{t}_{1} \quad=\text { Temperatur Awal }\left({ }^{\circ} \mathrm{C}\right) \\
& \mathrm{c}_{\mathrm{v}}=\text { Panas Jenis Alat }(\text { bomb Calorimeter }) \\
& \mathrm{m}_{\mathrm{bb}}=\text { Massa briket yang di uji }
\end{aligned}
$$

\section{HASIl dan Pembahasan}

Pada penelitian ini dipersiapkan bahan baku sebanyak mungkin untuk pembuatan dan pencetakan briket tebu tibarau. Kebutuhan bahan baku penelitian berupa ampas tebu tibarau dengan memprediksi terhadap banyaknya jumlah variasi campuran antara ampas tebu tibarau dengan perekat. Hal ini dilaksanakan berdasarkan alur pemikiran sesuai teknis pembuatan briket maka diperoleh beberapa protototype fisis hasil pengembangan pembuatan (Gambar 4).

Berdasarkan tatanan prosedur penggunaan alat Bomb Calorimeter tersebut maka diperoleh nilai pembakaran untuk briket tebu tibarau yang dihasilkan seperti pada Tabel 1. Nilai yang diperoleh sejumlah besaran fisika di dalam tabel 1 diturunkan berdasarkan formula yang baku dengan memasukkan data-data dari hasil pengukuran pada peralatan uji Bomb Calorimeter.

Dari hasil uji karakteristik nilai kalor briket tebu tibarau terhadap semua variasi dengan perekat yang berbeda. Dari semua perekat yang digunakan pada pembuatan briket tebu tibarau menunjukkan karakteristik yang berbeda-beda. Pencapaian nilai kalor yang maksimal sangat diperlukan dalam menganalisis kualitas briket. Briket tebu tibarau yang menggunakan perekat tanaman inggu, memiliki nilai kalor tertinggi sebesar 14608,36 $\mathrm{kJ} / \mathrm{Kg}$ dan densitas 302,98 $\mathrm{Kg} / \mathrm{m}^{3}$ dengan perbandingan komposisi $80 \%: 20 \%$.

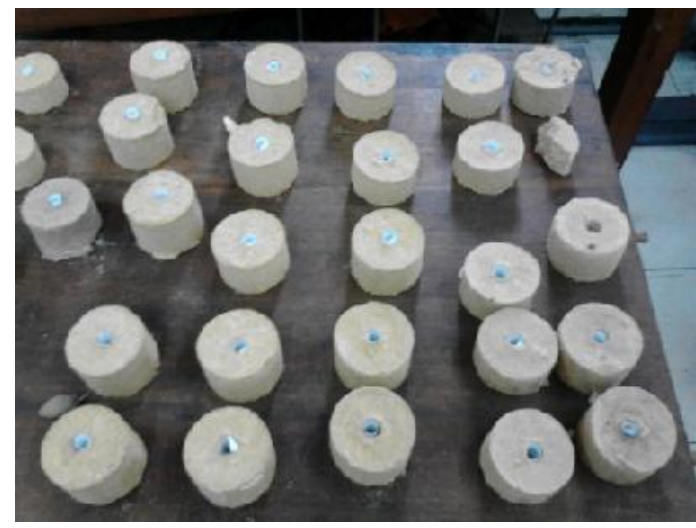

Gambar 4. Briket Tebu Tibarau

Hasil data analisis dapat dinyatakan bahwa komposisi yang memiliki nilai kalor tertinggi direkomendasikan untuk dapat dikembangkan sebagai bahan bakar energi alternatif. Namun perlu diperhatikan juga bahwa perekat yang umum dan mudah diperoleh menjadi prioritas utama digunakan dalam membuat briket.

\section{KESIMPULAN}

Dari penelitian ini dapat disimpulkan bahwa pemanfaatan tumbuhan tebu tibarau sebagai kandidat bahan baku briket dalam pengembangan energi terbarukan dapat dilakukan untuk mencapai ketahanan energi nasional. Karakteristik nilai kalor briket tebu tibarau yang tertinggi menggunakan perekat inggu yaitu $14608,36 \mathrm{~kJ} / \mathrm{Kg}$ dan densitas 
302,98 Kg/m $\mathrm{m}^{3}$ dengan perbandingan komposisi $80 \%$ : $20 \%$. Komposisi campuran antara bahan baku dengan perekat, besaran butir, gaya penekanan (kompaksi) sangat mempengaruhi karakteristik nilai kalor dan massa jenis briket tersebut.

\section{DAfTAR PUStaka}

[1] Pri Agung Rakhmanto, Ketahanan Energi Nasional Masih Rapuh, dalam Koran Kompas, (2013); Terbit Edisi Jumat 29 Nopembert 2013

[2] http://edukasi.kompas.com/

[3] Peraturan Presiden Republik Indonesia Nomor 5 Tahun 2006 Tentang Kebijakan Energi Nasional yang memuat ketentuan bahwa sumber energi alternatif tertentu adalah jenis sumber energi tertentu pengganti Bahan Bakar Minyak

[4] Peraturan Pemerintah Nomor 79 Tahun 2014 Tentang Kebijakan Energi Nasional

[5] Peraturan Presiden Republik Indonesia Nomor 41 Tahun 2016 Tentang Tata Cara Penetapan Dan Penanggulangan Krisis Energi dan/atau Darurat Enegi

[6] Grover,P.D \& Mishra,S.K (1996), Biomass Briquetting: Technology and Practices, Field Document No 46, FAO - Regional Wood Energy Development Program in Asia, Bangkok

[7] Departemen Energi dan Sumberdaya Mineral (2016); Statistik Energi Indonesia

[8] Syafi'i, W (2003); Hutan Sumber Energi Masa Depan, https://www.kompas.com/.

[9] Tyagi, V.K., Lo, S.L., Sludge: a waste or renewable source for energy and resources recovery. Renew. Sustainable Energy Rev., 25, 708, 2013.

[10] Hasanuddin \& Hendri Nurdin (2016); Pengembangan Bahan Bakar Bioethanol Dari Tumbuhan Tebu Tibarau Dengan Penambahan Zat Kapur Kulit Kerang Untuk Peningkatan Energi Panas, Laporan Penelitian Desentralisasi

[11] Hendri Nurdin \& Hasanuddin (2015); Design and Contructions of Simple Distilations Unit With Reflux Column Model For Cane Tibarau (Saccarum Spontaneous Linn) Bioethnol Productions, Proceeding International Conference ICOMSET, pp. 441 - 447, Oktober 2015

[12]Lalit K Singh, et al (2011), Utilization of hemicellulosic fraction of lignocellulosic biomaterial for bioethanol production, Journal Pelagia Research Library Adv. Appl. Sci. Res., 2011, 2 (5):508-521

\section{Biodata Penulis}

Hendri Nurdin lahir di Medan 28 Februari 1973 menamatkan pendidikan Sarjana pada bidang Ilmu Teknik Mesin di Medan. Kemudian melanjutkan studi dan memperoleh Magister Teknik di bidang Material \& Struktur (2006) di USU Medan. Sampai saat ini, merupakan staf pengajar di FT-UNP Jurusan Teknik Mesin. Pengalaman mengajar selama ini dalam mata kuliah Teknologi Bahan, Pengujian Bahan, Elemen Mesin, Mesin Teknologi Terapan, Fisika Teknik. Pengembangan bidang ilmu dilakukan melalui penelitian dengan fokus natural science materials. Pengembangan lanjutan diarahkan bernuansa penelitian bidang renewable energy \& natural science.

Hasanuddin lahir di Inuman - Indragiri, 20 Mei 1955, di FPTK IKIP Padang pada bidang Pendidikan Teknik Mesin. Kemudian melanjutkan studi di IPB Bogor dan memperoleh Magister Science di bidang Ilmu Perencanaan Pembangunan Wilayah \& Pedesaan (1993). Sampai saat ini, merupakan staf pengajar di FT-UNP Jurusan Teknik Mesin. Pengalaman mengajar selama ini dalam mata kuliah Mekanika Fluida, Mesin Teknologi Terapan, Manajemen Industri, Manajemen Operasi/Produksi, Kewirausahaan, Evaluasi Proyek. Pengembangan bidang ilmu dilakukan melalui penelitian dengan fokus konversi energi \& renewable (Kincir Angin) .

Darmawi lahir di Padang, 05 Maret 1954, menamatkan pendidikan Sarjana di FPTK IKIP Padang pada bidang Pendidikan Teknik Mesin. Kemudian melanjutkan studi di IKIP Jakarta dan memperoleh Magister Pendidikan di bidang Pendidikan Teknologi dan Kejuruan (1995). Sampai saat ini, merupakan staf pengajar di FTUNP Jurusan Teknik Mesin. Pengalaman mengajar selama ini dalam mata kuliah Statika Struktur, Mekanika Kekuatan Bahan, Matematika Teknik, Metode Mengajar Khusus, Fenomena Dasar Mesin. Pengembangan bidang ilmu dilakukan melalui penelitian dengan fokus Ilmu kependidikan \& Mekanika Teknik. 
